\title{
Evaluation of vegetable pigeonpea [Cajanus cajan (L.) Millsp] genotypes for yield stability
}

\author{
J. D. Ojwang ${ }^{1 *} \mathbb{0}$, R. Nyankanga', N. V. P. R. G. Ganga Rao ${ }^{1,2}$ and J. Imungi ${ }^{1}$
}

\begin{abstract}
Background: Vegetable pigeonpea is an important food security crop in the marginal dry areas of the Eastern region of Kenya. The adaptation and stability of vegetable pigeonpea genotypes across different agro-ecological zones in Kenya are not adequately determined. The objective of this study was to evaluate the yield stability and adaptability of genotypes: KAT 60/8, MZ 2/9, ICEAP 00554, ICEAP 00557 and KIONZA based on additive main effects and multiplicative interactions (AMMI) and Genotype plus genotype by environment (GGE biplot) analysis.

Methods: Evaluation of vegetable pigeonpea Genotypes was conducted at Kiboko, Katumani and Kambi ya Mawe research stations located in Eastern region and University of Nairobi Field station in central region of Kenya. The genotypes were planted in a Randomized Complete Block design (RCBD), replicated three times at all sites. Rainfall at Kiboko and Kabete were supplemented with irrigation, using sprinklers, for a total of 38 times, providing $832 \mathrm{~mm}$ of water. The crop was protected from pests by the application of broad-spectrum, non-systemic, pyrethroid alphacypermethrin and dimethoate, after field scouting. All other agronomic and cultural practices were done as recommended for each location.
\end{abstract}

Results: Combined analysis of variance (ANOVA) at six environments revealed highly significant $(P<0.01)$ variations in $\mathrm{G} \times \mathrm{E}$ interactions for yield ( $\mathrm{Kg} / \mathrm{ha}), 100$ Seed mass ( $\mathrm{g} / 100$ seed), days to flower and maturity $(P<0.05)$. AMMl model for grain yield interaction principal components analysis (IPCA), explained $96.5 \%$ of the total yield variation. The cultivar MZ 2/9 and KAT 60/8 recorded a lower IPCA1, indicating a wider adaptation and stability. Kambi ya Mawe, Katumani and Kiboko had higher IPCA1, indicating greatest interactive environments and adapted genotypes. Kambi ya Mawe, was the most ideal location for evaluating pigeonpea genotypes. While KIONZA was the most ideal genotype for yield performance, MZ 2/9 and KAT 60/8 were most stable with a wider adaptation.

Conclusion: KIONZA should be used as a reference genotype, while Kambi ya Mawe would be the most ideal location for testing the vegetable pigeonpea genotypes in breeding research. Increased deployment of stable pigeon pea cultivars, MZ 2/9 and KAT 60/8 would enhance food security in the dry areas of Eastern regions of Kenya. These genotypes need to be promoted with farmers for wider adoption in the Eastern region of Kenya.

Keywords: Multi-environmental trial, Additive main effects and multiplicative interactions (AMMI), Principal component analysis (PCA), GGE biplot, Kenya

*Correspondence: dojwang2012@gmail.com

1 Department of Plant Science and Crop Protection, University of Nairobi, Nairobi, Kenya

Full list of author information is available at the end of the article

\section{Background}

Pigeonpea is the third most important legume in Kenya, in terms of area of cultivation, subsequent to dry beans (Phaseolus vulgaries L.) and cowpea (Vigna unguiculata L.) (Mergeai et al. 2001). When harvested as green vegetables peas, the immature pods are harvested at physiological maturity, just before they lose their green colour. original author(s) and the source, provide a link to the Creative Commons licence, and indicate if changes were made. The images or other third party material in this article are included in the article's Creative Commons licence, unless indicated otherwise in a credit line to the material. If material is not included in the article's Creative Commons licence and your intended use is not permitted by statutory regulation or exceeds the permitted use, you will need to obtain permission directly from the copyright holder. To view a copy of this licence, visit http://creativecommons.org/licenses/by/4.0/. The Creative Commons Public Domain Dedication waiver (http://creativeco mmons.org/publicdomain/zero/1.0/) applies to the data made available in this article, unless otherwise stated in a credit line to the data. 
At this stage, the green seed is more nutritious than the dry seed as it has more protein and sugars than the dry mature seeds (Faris et al. 1987). A wide variability exists in the chemical composition of Pigeon peas seeds due to locations where they are produced and post-harvest management. Large immature seeds, long green pods and sweetness are the consumer preferred trait of vegetable pigeon pea (Upadhyaya et al. 2010).

Eastern Kenya is the most important pigeonpea producing region, accounting for slightly about 99 percent of total national production (Latha et al. 2008). Due to its nutritious content, pigeonpea is often used to supplement cereal-based diets and consequently, it is used extensively by many smallholder farmers in Kenya. Globally, the crop acreage is about 5.41 million hectares in 2017 (FAOSTAT 2018), with Kenya reporting $1,18,662 \mathrm{ha}^{-1}$. The crop has not achieved its production potential largely due to poor management practices, inadequate adaptation of genotypes (Silim et al. 2007), biotic and abiotic constraints.

The yield of grain pigeonpea yield varies from 300 to $500 \mathrm{~kg} / \mathrm{ha}^{-1}$ under farmer management in Kenya. This is lower than its potential yield under research conditions of 1500-2500 kg/ha (Mergeai et al. 2001). Much research work has focused on dry pigeon peas (Turner et al. 2003), with vegetable pigeonpea remaining largely under researched even though vegetable pigeonpeas has immense potential for the semi-arid regions of Eastern Kenya (Saxena et al. 2010). There is increasing market potential and demand for the vegetable pigeonpeas in the region given its potential for household incomes and food security (Shiferaw et al. 2008; Ojwang et al. 2016a-d).

Vegetable pigeonpea genotypes with potential for high yield under irrigation and rainfed production systems and with good acceptance by consumers have been identified (Ojwang et al. 2016a-d). However, their adaptation and stability across agro-ecological zones and the pigeonpea intensive production zones in Kenya are not adequately determined. Understanding the adaptation is critical to performance improvement and cultivar deployment in diverse cropping systems (Lule et al. 2014).

Several methods have been used for stability analysis and identification of crop cultivars with stable performance and positive response to diverse environmental conditions. These include Additive main effects and multiplicative interactions (AMMI) stability analysis, AMMI stability values (ASV) and yield stability values (YSV) which are based on the interaction principal components analysis (IPCA) scores (Mulema et al. 2004). Genotype plus genotype by environment (GGE biplot) analysis have also been used to extensively explore multienvironment trials (Hagos and Abay 2013), based on visual assessment of $\mathrm{G} \times \mathrm{E}$ interaction (GEI) pattern (Yan and Hunt 2001). The GGE biplot can be useful tool to display the data pattern, high-yield and stable cultivars (Yan et al. 2001). Stability of various crops have been studied by applying AMMI and GGE biplots successfully in soybean (Glycine max L. Meril) (Ikeogu and Nwofia 2013), sweet potatoes (Ipomoea batatas) (Osiru et al. 2009a, b; Moussa et al. 2011), finger millet (Eleusine coracana) (Lule et al. 2014), grain sorghum (Patil et al. 2007), and rice (Oryza sativa) (Islam et al. 2014). The objective of this research was to evaluate yield stability of pigeonpea genotypes based on AMMI and GGE biplot analysis.

\section{Methods \\ Description of the study location}

The study was conducted at Kiboko, Katumani, Kambi ya Mawe research Stations and University of Nairobi's field farm. Kiboko Rsearch Station is $975 \mathrm{~m}$ above sea level (m.a.s.l), under eco-climatic zone V (Michieka and Pouw 1977) (Table 1). Kambi ya Mawe has an elevation of 1250 m.a.s.l, located at elevation 1250 m.a.s.l.. Katumani is located in the Upper Middle Zone IV agro-ecological zone (AEZ) at an altitude of $1600 \mathrm{~m}$. Kabete Field station is located in agro-ecological zone II at 1850 m.a.s.l (Table 1). The soil PH across the locations ranged from 5.8 at Kabete to 6.2 at Kiboko and Kambi ya Mawe. Katumani reported a soil pH of 5.9. According to Mallikarjuna et al. (2011), pigeon peas tolerate $\mathrm{pH}$ values of 4.5-8.0. The soil $\mathrm{pH}$ at all locations were within this range.

The monthly rainfall $(\mathrm{mm})$ and temperature $\left({ }^{\circ} \mathrm{C}\right)$ were recorded at all locations in which this research was conducted. During 2016 long rains season, experiments

Table 1 Description of the experimental locations (2016-2017)

\begin{tabular}{|c|c|c|c|c|c|c|}
\hline Environment (E) & Altitude (M) & Latitude & Longitude & Rain (MM) & $\begin{array}{l}\text { Mean temp. } \\
\left({ }^{\circ} \mathrm{C}\right)\end{array}$ & Location (County) \\
\hline Katumani & 1600 & $1^{\circ} 35^{\prime} S$ & $37^{\circ} 14^{\prime} \mathrm{E}$ & 717 & 19.6 & Machakos \\
\hline Kambi ya Mawe & 1250 & $1^{\circ} 57^{\prime} S$ & $37^{\circ} 40^{\prime} \mathrm{E}$ & 550 & 22.0 & Makueni \\
\hline Kabete & 1850 & $1^{\circ} 15^{\prime} S$ & $36^{\circ} 44^{\prime} \mathrm{E}$ & 1100 & 20.0 & Kiambu \\
\hline Kiboko & 975 & $2^{\circ} 10^{\prime} S$ & $34^{\circ} 40^{\prime} \mathrm{E}$ & 561 & 24.0 & Makueni \\
\hline
\end{tabular}


were planted at Kiboko and Kabete locations. During the 2016/17 short rain season, experiments were planted at all locations (Kiboko, Kambi ya Mawe, Katumani and Kabete). Soil Samples were collected from all locations before land preparation was done.

\section{Description of the genetic materials}

Five medium duration pigeonpea genotypes: ICEAP 00557, ICEAP 00554, KAT 60/8, KIONZA and MZ 2/9, were used in this study. The cultivar ICEAP 00557 and ICEAP 00554 were selected from germplasm from Nachingewa in Tanzania by International Crops Research Institute for the semi-arid tropics (ICRISAT). The pigeonpea genotypes flower in 85-90 days and maturity duration is $150-160$ days. The potential yield of immature grain has been recorded at 7-10 tons per hectare. KAT $60 / 8$ was developed in Kenya, with plant height of $85-130 \mathrm{~cm}$, depending on the altitude and season, and has a spreading growth habit. KAT 60/8 develops flowers in 95-120 days. The cultivar MZ 2/9 was selected from germplasm collection in Mozambique by ICRISAT. It has early flower development, $80-100 \mathrm{~cm}$ (height), with seed mass of $30-40 \mathrm{~g} / 100$ seed. The cultivar, KIONZA is an early maturing local cultivar (120-220 days to flower) and grown by majority of farmers in the Eastern region of Kenya for both dry and green vegetable peas. The seeds planted in the experiments from ICRISAT's Kiboko and Kambi ya Mawe Research Stations.

\section{Experimental design and field management}

The 5 genotypes were planted in a randomized complete block design (RCBD), replicated three times at all sites in a field plot of $3.0 \times 4.5 \mathrm{~m}$, with $1 \mathrm{~m}$ between plots and $1.5 \mathrm{~m}$ between blocks keeping inter and intra row spacing of $1.5 \mathrm{~m}$ and $0.3 \mathrm{~m}$, respectively as in previous experiments (Ojwang et al. 2016a,b). Each plot had a total of 3 rows. Seeds were drilled at a depth of $10 \mathrm{~cm}$. Rainfall at Kiboko (E4) was supplemented with irrigation, using sprinklers, for a total of 38 times, providing $832 \mathrm{~mm}$ of water. Seedlings were thinned to one plant per hill two weeks after germination, to a spacing of $30 \mathrm{~cm}$. Fields were weeded by hand. The crop was protected from pod borers, pod suckers, and pod flies by the application of broad-spectrum, non-systemic, pyrethroid alpha-cypermethrin and dimethoate, a systemic organophosphate, after field scouting. Cypermethrin was mixed and applied at rate of $1.25 \mathrm{~L} \mathrm{ha}^{-1}$ (equivalent to $25 \mathrm{~mL}$ in $20 \mathrm{~L}$ of water), while $35 \mathrm{ml}$ of dimethoate, was applied at the rate of $10,00 \mathrm{~L} \mathrm{ha}^{-1}$. All other agronomic and cultural practices were done as recommended for each location.

\section{Data collection}

Data were collected on eleven crop variables, which included: (1) days to 50 percent flowering (days), (2) days to harvesting (days), (3) seed per pod (numbers), (4)100 fresh seed weight (grams), (5) pod + grain and grain weight (grams), (6) pod length and width $(\mathrm{cm}),(7)$ pods per plant at harvest (number), (8) plant height at maturity (CM), (9) shelling ratio (\%), (10) number of racemes per plant (number) and (11) primary and secondary branches (number). The data were collected from five plants in the mid row of the plot of three lines, based on the guideline outlined in International Board for Plant Genetic Resources (IBPGR and ICRISAT 1993). The weather data collected included daily rainfall, maximum and minimum daily temperature and mean daily temperature at different phases of growth.

\section{Statistical analysis of data}

The homogeneity of variances was tested by Bartlett test before combined statistical analyses were performed. Analysis of variance (ANOVA) for genotypes for quantified variables, at each location, followed by a combined analysis of variance, to partition environment (E), genotypes $(G)$ and the $G \times E$ interactions were done. The mean values showing significance of the genotypes for each parameter were further evaluated by using least significant difference (LSD) test at $\mathrm{P}<0.05$ level of probability, using Fisher's protected least significant difference test. The model employed in the analysis was:

$$
Y i j k=\mu+G i+E j+B k+G E i j+\varepsilon i j k
$$

where Yijk is the observed mean of the ith genotype, (Gi) in the ith environment, $(\mathrm{Ej})$, in the jth block (Bk); $\mu$ is the overall mean; $\mathrm{Gi}$ is effect of the ith genotype; $\mathrm{Ej}$ is effect of the jth environment; Bk is block effect of the ith genotype in the jth environment; GEij is the interaction effects of the ith genotype, and the jth environment; and eijk is the error term. AMMI analysis was undertaken, using GenStat 15th Edition (GenStat 2015). The yield stability of genotypes was computed by using the additive main effects and multiplicative interaction (AMMI) model (Gauch and Zobel 1997) as described in the equation:

$$
Y i j=\mu+G i+E j+\Sigma k=1 \lambda k \gamma i k \alpha j k+\rho i j+\varepsilon i j
$$

where Yij is the yield of genotype $i$ in environment $j ; \mu$ grand mean; Gi the genotype mean deviations (the genotype means minus the grand mean); Ej the environment mean deviations; $\lambda \mathrm{k}$ the singular value for the PCA axis $\mathrm{k} ; \gamma$ ik and $\gamma \mathrm{ik} \alpha j \mathrm{k}$ are the genotype and environment PCA 
scores for PCA axis $\mathrm{k}$; $\mathrm{K}$ is the number of PCA axes; pij is the additional residue and $\varepsilon \mathrm{ij}$ is the ijth error associated with the model replicated, an error term eijr, which is the difference between the Yij mean and the single observation for replicates, should be added. AMMI stability value (ASV) was determined using the formula developed by Purchase (1997), while yield stability index (YSI) was computed by summing up the ranks from ASV and mean seed yield, as previously described (Farshadfar et al. 2011). GGE Biplot analysis (Yan 2001) was done based on the GenStat Statistical Analysis (GenStat 15th Edition, GenStat 2015), to graphically visualize the relationships between genotypes and environment. Comparisons of biplots, scatter biplots, and ranking biplots were generated for genotype ranking.

\section{Results and discussions}

\section{Climatic data at the experimental locations}

The rainfall and temperature at the multi-locational experiments varied. Kabete received a total of $899.3 \mathrm{~mm}$ of rainfall in 48 days, compared to $179 \mathrm{~mm}$ at Kiboko, in 19 days. Rainfall at Kiboko was supplemented by irrigation, providing an equivalent of $832 \mathrm{~mm}$ for that season. Ambient temperatures were relatively cooler $\left(18{ }^{\circ} \mathrm{C}\right)$ at Kabete, compared to Kiboko $\left(24{ }^{\circ} \mathrm{C}\right)$. Kabete reported lower temperatures $\left(19{ }^{\circ} \mathrm{C}\right)$, followed by Katumani $\left(20^{\circ} \mathrm{C}\right)$, Kambi ya Mawe $\left(24^{\circ} \mathrm{C}\right)$ and Kiboko $\left(25^{\circ} \mathrm{C}\right)$. Rainfall also followed the same trend, with Kiboko receiving 296 mm, Katumani, 505 mm, Kambi ya Mawe, 708 mm and Kabete, $745 \mathrm{~mm}$. The soil pH ranged from 5.8 at Kabete to 6.2 at Kiboko and Kambi ya Mawe. Katumani had a soil $\mathrm{pH}$ of 5.9. According to Mallikarjuna et al. (2011), pigeonpeas tolerates $\mathrm{pH}$ values of 4.5-8.0. Kiboko reported higher levels of Calcium $(7.0 \mathrm{cmol} / \mathrm{Kg})$, Phosphorus (65.6 ppm), Manganese (89.5 ppm) and Sodium $(0.9 \mathrm{cmol} / \mathrm{Kg})$. The rainfall amounts, temperature and soil characteristics were within the range required by pigeonpea for growth and development.

\section{Analysis of variance and performance of genotypes at the different locations}

Genotype (G), environment (E) were highly significant $(P<0.001)$ while $\mathrm{G} \times \mathrm{E}$ interaction $(\mathrm{GEI})$ were significant $(P<0.05)$ for grain yield (Table 2$)$. Genotypes contributed $9 \%$ of the total variations, while environment contributed $49.6 \%$ and the interactions of $\mathrm{G} \times \mathrm{E}(\mathrm{GIE})$ contributed $19.6 \%$ of the variation (Table 3 ). The combined analysis showed significant GIE interaction for yield $(P<0.05)$, seed mass $(P<0.05)$, days to flower $(P$ $<0.001)$, and maturity $(P<0.001)$. Similarly, the number of pods per plant $(P<0.05)$, number of racemes per plant $(P<0.001)$, number of secondary branches $(P<0.05)$, and plant height $(\mathrm{cm})$ were also significant $(P<0.001)$ (Table 3$)$. The local check cultivar, Kionza recorded a significantly $(P<0.01)$ greater mean yield, of $1349 \mathrm{~kg} /$ ha, followed by MZ 2/9, with $932 \mathrm{~kg} / \mathrm{ha}$ (Table 3). The $\mathrm{G}, \mathrm{E}$ and $\mathrm{G} \times \mathrm{E}$ effects on yield in this trial was similar to what has been reported for chickpeas (Ashango et al. 2016, Sreelakshmi et al. 2010 and Pagi et al. 2017) and on grain pigeonpeas.

Pigeonpea yield at Kiboko location (March planting) was significantly $(P<0.05)$ greater, $(1695 \mathrm{~kg} / \mathrm{ha})$ than the other location; followed by Kambi ya Mawe (1379 kg/ ha) and Katumani (1020 kg/ha) locations (Table 4). The effect of $\mathrm{G} \times \mathrm{E}$ was indicated by changes in relative ranking of genotypes across locations (Table 4). This implies

Table 2 Combined AMMI model analysis of variance for grain yield of vegetable pigeonpea genotypes evaluated at six locations in Kenya (2016-2017)

\begin{tabular}{|c|c|c|c|c|c|c|}
\hline Source & df & TSS & TSS\% & $\mathbf{G} \times \mathbf{E}$ explained & Cumulative (\%) & MS \\
\hline Genotypes & 4 & $33,06,164$ & 9.1 & - & - & $8,26,541^{* * *}$ \\
\hline Environments & 5 & $18,103,375$ & 49.6 & - & - & $36,20,675^{* * *}$ \\
\hline Block (within environ) & 12 & $10,21,597$ & 2.8 & - & - & 85,133 NS \\
\hline GIE interactions & 20 & $71,62,881$ & 19.6 & - & - & $3,58,144^{* *}$ \\
\hline IPCA 1 & 8 & $55,16,967$ & - & 77.0 & 77.0 & $6,89,621^{* * *}$ \\
\hline IPCA2 & 6 & $13,96,489$ & - & 19.5 & 96.5 & $2,32,748 \mathrm{NS}$ \\
\hline Residuals & 6 & $2,49,426$ & - & - & - & $41,571 \mathrm{NS}$ \\
\hline Error & 48 & $69,34,666$ & 410.4 & - & - & $1,44,472$ \\
\hline Total & 89 & $36,538,683$ & 35 & - & - & - \\
\hline
\end{tabular}

NS non-significant; SS sum of square; $d f$ degree of freedom; TSS total sum of square; MS mean square; IPCA interaction principal component analysis; GIE genotype $x$ environment interaction

${ }^{*} P<0.05$

**P $<0.01$

***P $P<0.001$ 
Table 3 Yield (Kg/ha) of five vegetable pigeonpea genotypes evaluated across six environments in Kenya (2016-2017)

\begin{tabular}{lccccccc}
\hline Genotypes & KAT (E1) & KYM (E2) & KAB S2 (E4) & KAB S1 (E4) & KIB S1 (E5) & KIB S2 (E6) & Mean yield \\
\hline ICEAP 00554 & $1160^{\mathrm{a}}$ & $711.0^{\mathrm{b}}$ & 709.0 & 478.0 & 1613.0 & 559.0 & 871.7 \\
ICEAP 00557 & $867.0^{\mathrm{bc}}$ & $958.0^{\mathrm{b}}$ & 622.0 & 437.0 & 1679.0 & 406.0 & 828.2 \\
KAT 60/8 & $669.0^{\mathrm{c}}$ & $1099.0^{\mathrm{b}}$ & 857.0 & 264.0 & 1909.0 & 473.0 & 878.5 \\
KIONZA & $1083.0^{\mathrm{ab}}$ & $2754.0^{\mathrm{a}}$ & 1243.0 & 572.0 & 1687.0 & 759.0 & 1349.7 \\
MZ 2/9 & $1323.0^{\mathrm{a}}$ & $1377.0^{\mathrm{b}}$ & 381.0 & 566.0 & 1588.0 & 359.0 & 932.3 \\
Mean & 1020.4 & 1379.8 & 762.4 & 463.4 & 1695.2 & 511.2 & 972.1 \\
SEM & 87.0 & 354.8 & 184.1 & 122.1 & 302.6 & 124.0 & 213.8 \\
SE & 150.6 & 612.7 & 318.9 & 215.0 & 524.1 & 214.7 & 370.3 \\
SED & 123.0 & 500.3 & 260.4 & 175.5 & 427.9 & 175.3 & 302.4 \\
LSD > 0.05 & $283.6^{* *}$ & $1153.7^{*}$ & $600 \mathrm{NS}$ & $404.8 \mathrm{NS}$ & $986.8 \mathrm{NS}$ & $404.3 \mathrm{NS}$ & $270.7^{* * *}$ \\
CV\% & 14.8 & 44.4 & 41.8 & 46.4 & 30.9 & 42.0 & 38.1 \\
\hline
\end{tabular}

SEM SED; LSD least square difference; CV coefficient of variation; KAT Katumani; KYM Kambi ya Mawe; KAB: Kabete; KIB Kiboko; $E$ environment; NS non-significant Means followed by the same superscript letter do not differ significantly $(P>0.05)$ within the same column at:

${ }^{*} P<0.05$

**P $P<0.01$

*** $P<0.001$

Table 4 Average yield (Kg/ha) for the five vegetable pigeonpea genotype, the magnitude (absolute value) of the IPCA's scores and stability parameters from AMMI model

\begin{tabular}{lllrrrrr}
\hline Genotype & Average (Kg/Ha) & Rank (yield) & IPCAg (1) & IPCAg (2) & ASV & $\begin{array}{c}\text { Rank (ASV) } \\
\text { Yield } \\
\text { stability } \\
\text { index }\end{array}$ \\
\hline KIONZA & 1349.7 & 1 & -31.38836 & 0.98557 & 124.0 & 5 & 6 \\
MZ 2/9 & 932.3 & 2 & 1.93568 & -19.21366 & 20.7 & 1 & 3 \\
KAT 60/8 & 878.7 & 3 & 4.38311 & 17.35355 & 24.5 & 2 & 5 \\
ICEAP 00554 & 871.8 & 4 & 16.63744 & -1.86583 & 65.8 & 4 & 8 \\
ICEAP 00557 & 828.2 & 5 & 8.43214 & 2.74037 & 33.4 & 3 & 8 \\
\hline
\end{tabular}

that different genotypes are adapted to different environmental conditions, suggesting the need to select environment specific cultivars. Similar recommendations have been suggested in chickpeas (Ashango et al. 2016), grain pigeon cultivars (Sreelakshmi et al. (2010) and on sorghum cultivar selection (Sameer 2018; Mare et al. 2017 and Gasura et al. 2015).

\section{Genotype adaptation and yield stability}

The AMMI model for grain yield showed that $G \times E$ interactions $(\mathrm{GEI})$, were significant $(P<0.01)$ (Table 4$)$. Our research results agree with previous findings grain pigeonpeas (Pagi et al. 2017; Phad et al. 2005; and Sameer Kumar 2010). Two IPCAs from the interaction components, explained $96.5 \%$ of the variability in grain yield (Table 4). Hintsa and Abay (2013) reported similar observation in bread wheat, (Tamene et al. 2013; Shitaye 2015; Tesfaye et al. 2008) in field peas. Only IPCA1 were significant at $(P<0.01)$ for yield (Table 3$)$. The use of only one significant IPCA1, to adequately explain the interaction between genotype and environment and their adaptation has been applied in barley (Gebremedhin et al. 2014), potato cultivars (Mulema et al. 2008) and sweet potato cultivars (Osiru et al. 2009a, b) (Table 4).

The first IPCA sum of squares (TSS) was greater than the second IPCA 2, indicating differences in vegetable pigeonpea yield performance among genotypes as a result of the GIE. Compared to other genotypes, KIONZA, a local check cultivar, had a significantly $(P<0.05)$ high yield across locations, with a mean yield of $1349.7 \mathrm{~kg} /$ ha (Table 5). The cultivar ICEAP 00557 had the least yield among genotypes $(828.2 \mathrm{~kg} / \mathrm{ha})$, but did not significantly $(P>0.05)$ differ from ICEAP 00554 and KAT $60 / 8$ (Table 2). The IPCA scores of a genotype is indicative of stability or adaptation over environments (Hagos and Abay 2013). The greater the IPCA scores, the more adapted is a genotype to certain environments (Hagos and Abay 2013; Mulema et al. 2008). IPCA score close to zero indicates how stable or adapted the genotype is over all the locations under evaluation. In this experiment, 
Table 5 Mean yield (Kg/ha) of pigeon pea cultivars in the six environments, the magnitude (absolute value) of the IPCA's scores and stability parameters from AMMI Model

\begin{tabular}{|c|c|c|c|c|c|c|c|}
\hline Environment & EM & Yield rank & IPCAe (1) & IPCAe (2) & ASV & Rank (ASV) & YSI \\
\hline Kiboko October (E5) & 1695.2 & 1 & 10.856 & 9.631 & 44.0 & 5.0 & 6.0 \\
\hline Kambi ya Mawe (E2) & 1380.0 & 2 & -32.328 & -3.907 & 127.8 & 6.0 & 8.0 \\
\hline Katumani (E1) & 1020.7 & 3 & 9.832 & -17.339 & 42.5 & 4.0 & 7.0 \\
\hline Kabete March (E3) & 762.5 & 4 & -1.679 & 14.435 & 15.9 & 1.0 & 5.0 \\
\hline Kiboko March (E4) & 511.3 & 5 & 5.088 & 4.126 & 20.5 & 2.0 & 7.0 \\
\hline Kabete October (E6) & 463.1 & 6 & 8.231 & -6.945 & 33.3 & 3.0 & 9.0 \\
\hline
\end{tabular}

E1-E6 environment; $E M$ environment mean yield score; ASV AMMI stability value; YSI yield stability index

the genotypes KIONZA (IPCA-31.3) and ICEAP 00554 (IPCA-16.64), had higher IPCA1 scores implying that they were most unstable genotypes, as the interaction component were large and could be considered as having specific adaptation to a given environment. On the other hand, MZ 2/9 (IPCA-1.93) and KAT 60/8 (IPCA-4.38) had lower IPCA1 scores, and therefore had the lowest contribution to the interaction components, indicating a wider adaptation and high stability. Previous research has documented specific adaptation of potato and sweetpotato genotypes (Mulema et al. 2008; Osiru et al. 2009a, b),

\section{Location adaptation and stability analysis}

The Kiboko location had the highest pigeonpea yield $(1695 \mathrm{~kg} / \mathrm{ha})$ during the short rainy season, followed by Kambi ya Mawe (1380 kg/ha), Katumani $(1021 \mathrm{~kg} /$ ha), Kabete (Short rainy season, March 2016 planting) $(762.5 \mathrm{~kg} / \mathrm{ha}$ ) and Kabete, (long rainy season, October 2016 planting) with $463 \mathrm{~kg} / \mathrm{ha}$ (Table 5). The high yields at Kiboko resulted from supplementary irrigation that could have provided increased water availability for pod development and crop maturity. Similar results have been reported previously (Ojwang et al. 2016a-d). In general, the locations with higher IPCA1 scores, such as Kambi ya Mawe (32.3), Katumani (9.8) and Kiboko (5.0), recorded higher yields. Therefore, this indicated that the environments had greatest interactions with the genotypes were most suitable for genotypes with specific adaptation such as KIONZA. Locations with lower IPCA scores such as Kabete (1.67), at season 1, March planting, Kiboko (5.09), season 1-March Planting and Kabete (8.2), season 2-October planting, indicated stable locations and are generally suitable for evaluation of genotypes. Similar observations have been made on sweet sorghum (Rono et al. 2016) and on pigeonpeas (Pagi et al. 2017).

\section{AMMI stability value (ASV)}

AMMI stability value (ASV) has been described as the distance from the coordinate point of origin in a twodimensional scatter plot of IPCA1 against IPCA2 scores in AMMI model (Purchase and Hatting 2000). Genotypes with the least ASV were the most stable. Therefore, genotypes MZ 2/9 and KAT 60/8 with ASI stability values of 20.7 and 24.5 had general adaptation and greater stability. Kambi ya Mawe (127), Kiboko (44, season 2) and Katumani (42.5) had the highest ASV, indicating unstable environments for vegetable pigeonpea yield. Kiboko (20.5, season 1-March), Kabete (15.9, season 1) and Kabete (season 2-October) had the lowest ASV, indicating high stability locations for yield evaluation of vegetable pigeonpea (Table 5).

\section{Yield stability index (YSI)}

Yield stability index (YSI) computed by summing the rank of mean yield across environments and the rank of AMMI stability values of genotypes has also been used in genotype selection (Farshadfar 2008). Genotypes with the lowest YSI had high mean yield and stability and therefore, were desirable. For example, in this research, MZ 2/9 and KAT 60/8 had 3 and 5 YSI values, respectively), showing that lower YSI values are indicative of high levels of stability with general cultivar adaptation. The cultivars ICEAP 00554, ICEAP 00557, and KIONZA had higher YSI values of 8,8 , and 6 , respectively; indicating high levels of instability but more specific adaptation to particular locations (Table 5). Rono et al. (2016) made similar observations based on the YSI values for sweet sorghum.

\section{GGE biplot analysis}

The GGE biplot analysis combines both genotype $(G)$ and GE interaction effects and graphically displays GE interaction in a two-way table as previously described (Yan et al. 2001). The responsive locations have been described as located far from the axis of the plots (Mare et al. 2017). Scatter plot analysis indicated that Environment 5-E5 (Kiboko, season 2), Environment 6-E6 (Kabete, Season 2) and Environment 4-E4 (Kiboko, season 1) were the most responsive test locations but had poor delineation ability. Kambi ya Mawe (Environment 2-E2), had both 


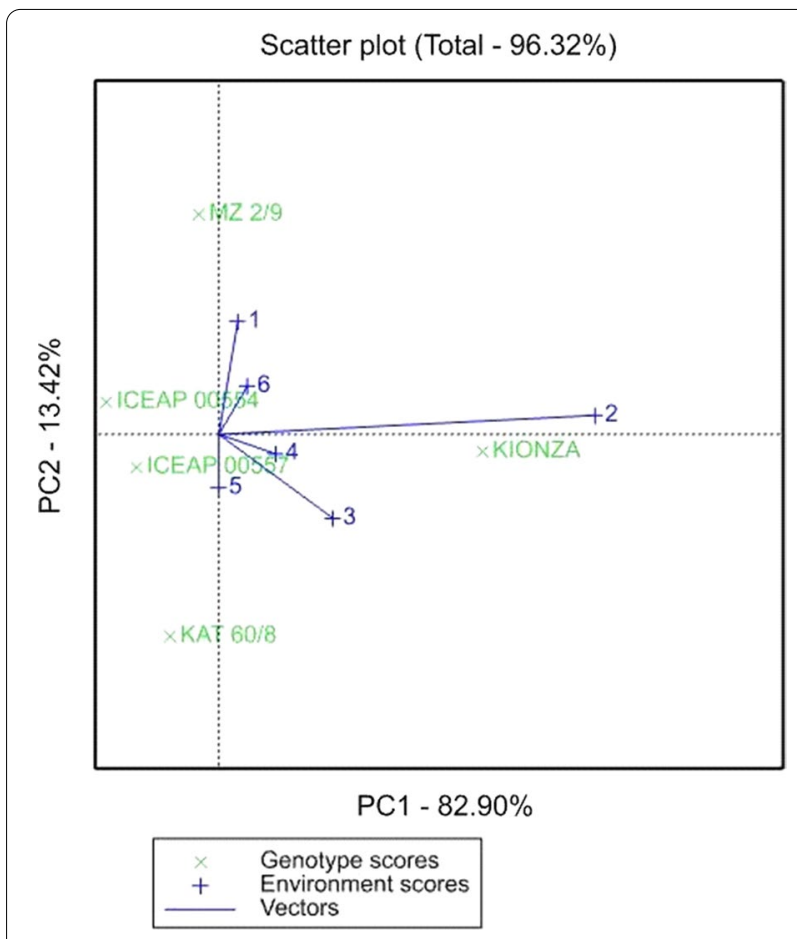

Fig. 1 The Environment vector view of the GGE drawn to show similarities among the test environments in discriminating environments

the delineation and representative ability, as evidenced by lengthy distance from the center of the plots, and with larger IPCA1 scores (- 32.31) relative to lower IPCA2 scores $(-3.907)$, making it an ideal and excellent location for evaluation of vegetable pigeonpea genotypes (Fig. 1).

We postulate that testing genotypes at Kambi ya Mawe during the October rains, which normally the planting season at this location, would give more information on the performance of genotypes compared to other locations. Test locations which are discriminatory but nonrepresentative, such as Environment 3-E3 (Kabete, season 1), Environment 1-E1 (Katumani) could be used for future selection of genotypes with specific adaptation, such as KIONZA and ICEAP 00554. However, Environment 5-E5 (Kiboko, season 2, October Planting) may not be an ideal test location for selecting vegetable pigeonpea genotypes with wider adaptation to entire region. In comparison, the biplot analysis of Environment 2-E2 (Kambi ya Mawe) was observed to be within the intrinsic cycle (Fig. 2). This location had larger IPCA1 scores $(-32.32)$ and lower IPCA2 scores $(-3.907)$. Previous research reported that the test environments should have large PC1 scores in order to discriminate genotypes for genotypic main effect and absolute small PC2 scores to be more representative of the overall locations (Yan and

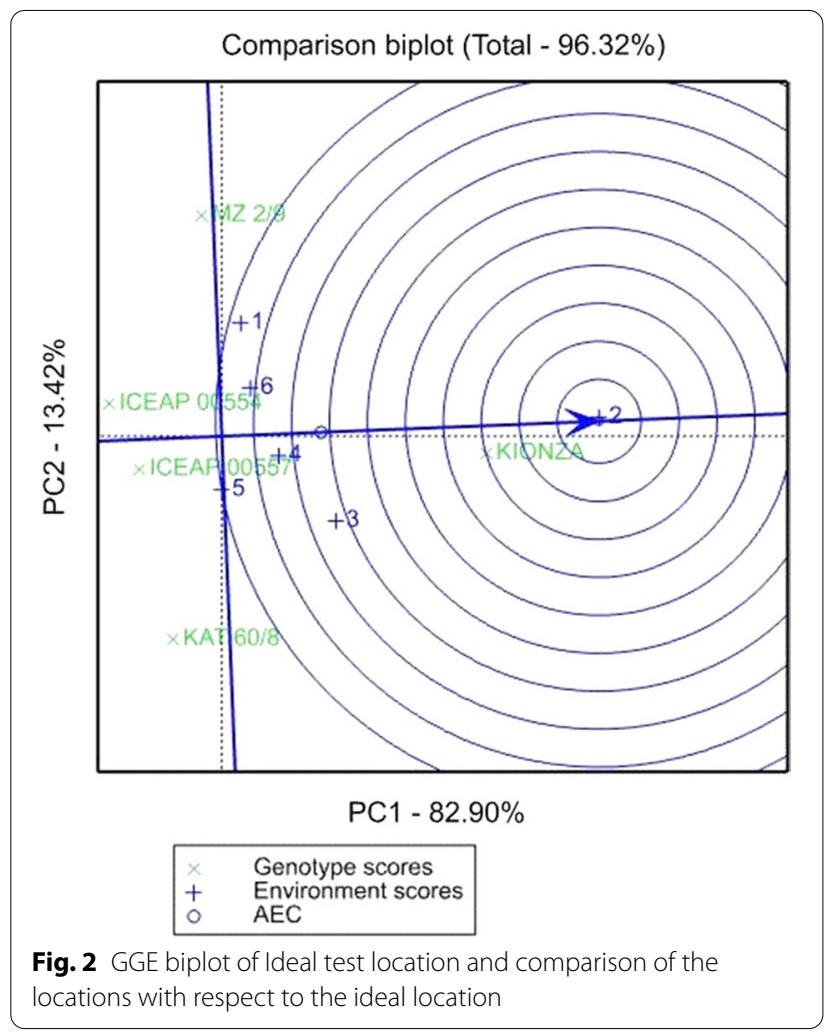

Rajcan 2002). Therefore, Kambi ya Mawe is more suitable for all vegetable pigeonpea genotypes, followed by Environment 3-E3 (Kabete-season 2) and Environment 4E4 (Kiboko, season 1).

In this research, we observed that the cultivar KIONZA was an ideal genotype, as shown by its proximity to the concentric circle in GGE biplot (Fig. 3), followed by MZ 2/9, KAT 60/8, ICEAP 00557 and lastly ICEAP 00554. It has been shown that the genotype with concentric circles previously exhibited high mean yield and therefore designated as an ideal genotype (Kaya et al. 2006 and Mitrovic et al. 2012). The cultivars ICEAP 00554 and ICEAP 00557 showed the worst performance genotypes in terms of stability as they were located further from the center of concentric circle. Therefore, KIONZA could be used as a reference genotype for future vegetable pigeonpea evaluation and plant breeding research. Estimation of yield and stability has been done using the average environment coordinator (AEC) method in which the highest yielding and stable genotypes across the test environments were designated as ideal (Yan and Kang 2003). Similarly, the genotype with limited $\mathrm{G} \times \mathrm{E}$ interaction and broadest 


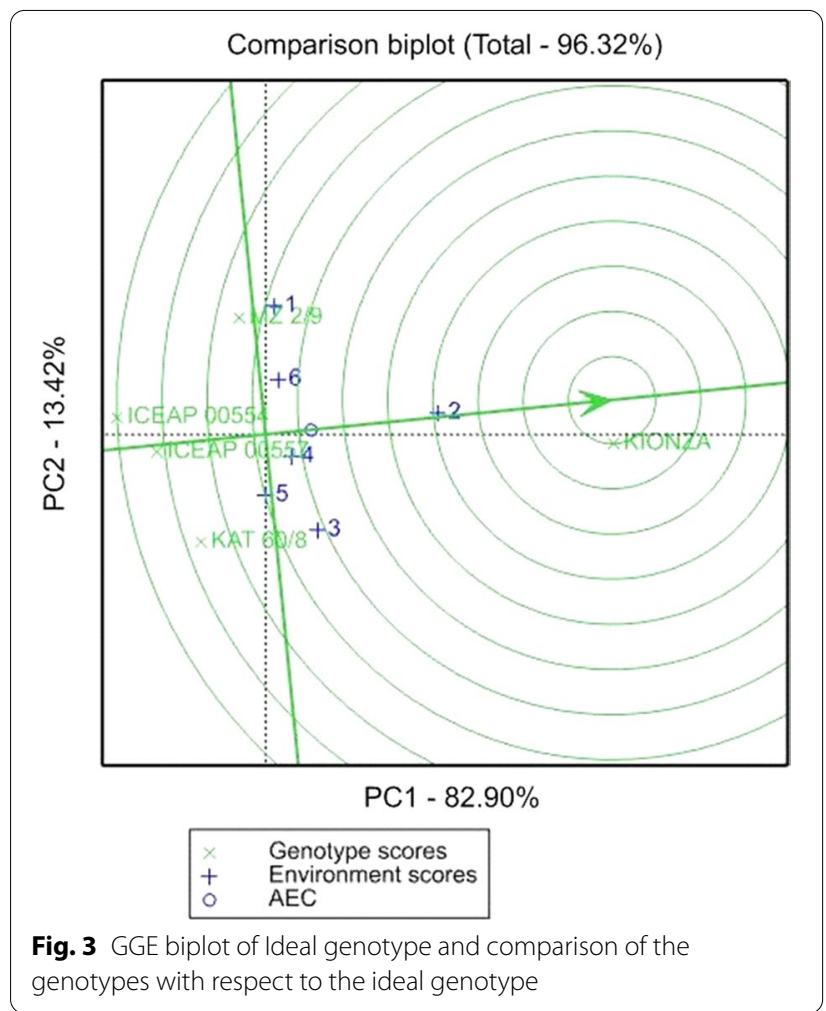

adaptation would possess both high mean performance and high stability within mega environments.

\section{Conclusions}

We evaluated the stability and high yield potential of pigeonpea genotypes based on combined ANOVA, AMMI and GGE biplot analysis. The cultivars MZ 2/9 and KAT $60 / 8$ had the least interaction components, indicating a wider adaptation and greater stability. The locations of Kambi ya Mawe, Katumani and Kiboko (season 2), had the greatest interactive environmental components, showing their suitability for specific adaptation of genotypes. The results of ASV and YSI analysis demonstrated that either methods could be used to assess stability and adaptation of vegetable pigeonpea genotypes. The GGE biplot analysis indicated that Kambi ya Mawe location was discriminatory and representative, making it the ideal and best locations for evaluation of vegetable pigeonpea genotypes. Overall, KIONZA was the best genotype, followed by MZ 2/9, KAT 60/8, ICEAP 00557 and least ICEAP 00554. This research identified three mega-environments: (1) Katumani (season 2); (2) Kambi ya Mawe and Kabete (season 1), and Kiboko (season 1); and (3) Kiboko (season 2). The best perfroming genotypes in these environments were: MZ 2/9 (Katumani and Kiboko); KIONZA Kambi ya Mawe, Kabete (season 1) and Kiboko (season 1); Kat 60/8 at Kiboko (season 2). We propose that KIONZA should be used as a reference genotype for future vegetable pigeonpea breeding research and evaluation, while Kambi ya Mawe was identified as the most ideal location for testing the genotypes. Increased deployment of stable pigeon pea cultivars, $\mathrm{MZ}$ 2/9 and KAT 60/8 would enhance food security utilization in the dry eastern regions of Kenya. The ministry of agriculture and other development partners need to take up these cultivars and promote them to farmers for wider adoption in Katumani, Kambi ya Mawe and Kiboko environments.

\section{Acknowledgements}

We acknowledge the support from the University of Nairobi, Kenya Agriculture and Livestock Research organization (KALRO) through its Kiboko, Katumani and Kambi ya Mawe research stations and International Crops Research Institute for the Semi-Arid Tropics (ICRISAT), Nairobi, Kenya.

\section{Authors' contributions}

JDO_- designed, monitored, collected data, analyzed and wrote the manuscript. Prof. RON: 1st supervisor: review and supervision. Prof. Jl: 2nd supervisor: review and supervision of laboratory and sensory work. Dr. GR 3rd supervisor: review and supervision. All authors read and approved the final manuscript.

\section{Authors' information}

David Ojwang is a PhD student at the University of Nairobi, Collage of agriculture and Veterinary Sciences (CAVS), department of Plant science and crop protection. On full time, he works as the Director of Programs at Heifer Project International, Heading Kenya programs in Dairy, Poultry and Beef. Previously, 2014-2016 he worked as the Regional Food Security Specialist, with Solidaridad EA, as the Food security specialist in Eastern and Central Africa region. Before Solidaridad, 2009-2014, he worked with FINTRAC, a USAID-Kenya Contractor, for 5 years as the Eastern, Coastal and Nyanza Regional Field Manager in a USAID Funded Kenya Horticulture Competitiveness Project. He holds an Msci (Horticulture) degree from the University of Nairobi, and BSc (Agric) from the same University. E-mail: dojwang2012@gmail.com.

Professor (Dr.) J. K. Imungi has a M.Sc. degree in Food Science and Technology from the Swiss Federal Institute of Technology Zurich/University of Nairobi. He has a Ph.D. (Food Science) from Cornell University, Ithaca, USA. He is currently a Professor in the Department of Food Science, Nutrition and Technology at the University of Nairobi, Kenya. Besides academic work, he has many administrative appointments such as Chairman, Department of Food Science and Technology (Feb 1992-1998) and Dean, Faculty of Agriculture, University of Nairobi, Kenya (Feb 1998-2003). He has also been involved in many consultancy activities for various agencies particularly as Consultant Food Scientists under Agricultural Technology Development and Transfer (ATDT) Rwanda (2004-2006) and many other International and National Agencies. Professor Imungi has supervised over 30 M.Sc. and Ph.D. students and has taught various courses related to Food Technology, Food Chemistry and Post-harvest of agronomic and horticultural crops. He has over 120 publications in reputable International and National journals. E-mail: imungijk@yahoo.com.

Prof. Richard Nyankanga is a senior Lecturer in the Department of Crop Science and Protection at the University of Nairobi (Kabete Campus). His research interests are in crop production and protection, crop farming systems and resource use analysis. Other keen interests are farmers' knowledge and the use of indigenous knowledge, seed systems and effects of climate change on crop productivity. He has participated in Crop advisory and extension services by advising farmers on agricultural practices in Non-Governmental Organizations and Youth groups as well as advising private horticultural firms and farms in Kenya. He has been involved in consultancy activities with International Agencies (e.g., International Potato Center) and private agricultural firms. He has also been involved as a stakeholder in the development of Policy on Horticultural Industry and development of short courses for horticultural farms. 
Richard has supervised various M.Sc. and Ph.D. students and teaches various courses in the Department of Crop Science and Crop Protection. He has over 50 publications in reputable National and International journals. Dr. Nyakanga has an M.S. and a Ph.D. in Horticulture and International Development from Cornell University, Ithaca, USA. E-mail: richard.nyankanga@uonbi.ac.ke. Dr. Ganga Rao is a Principal Scientist (Product Placement Lead) working at the International Crops Research Institute for the Semi-Arid Tropics (ICRISAT), Nairobi, Kenya with 22 years of crop breeding experience on wheat, castor bean, pigeonpea and chickpea in India and Africa-in a multi-cultural and multidisciplinary setting. Responsible for development and release of 3 wheat, 15 pigeonpea and 15 cultivars and registration of 6 wheat genetic stocks. During 12 years of working in Eastern and Southern Africa, worked closely with NARES in several countries for varietal development, testing, release and promotion in smallholder farmers. His keen passion on genetic enhancement and pre-breeding that resulted in developing unique products like high seed mass in bread wheat, and dual purpose, pest tolerant and bold seeded pigeonpea. He led many cooperative engagement efforts between national breeders and seed industry partners, which has helped synergize forces and deliver results. He mentored many national and private seed industry researchers and organized numerous trainings and field days, for stakeholders to disseminate best varieties and technologies. Email: N.Gangarao@cgair.org.

\section{Funding}

This research did not receive any specific Grant from funding agencies in the public, commercial, or not-for-profit sectors.

\section{Availability of data and materials}

The datasets during and/or analysed during the current study available from the corresponding author on reasonable request.

\section{Declarations}

\section{Ethics approval and consent to participate}

Permission has been obtained and that all study/experimental protocols involving plant materials was conducted in accordance with ICRISAT, National, and international guidelines and legislation.

\section{Consent for publication}

"Not applicable" in this section.

\section{Competing interests}

The authors declare that they have no competing interests.

\section{Author details}

'Department of Plant Science and Crop Protection, University of Nairobi, Nairobi, Kenya. ${ }^{2}$ International Crops Research Institute for Semi-Arid Tropics (ICRISAT), Nairobi, Kenya.

Received: 24 June 2021 Accepted: 11 October 2021

Published online: 30 October 2021

\section{References}

Ashango Z, Amsalu B, Tumisa K, Negash K, Fikre A. Seed yield stability and genotype $\times$ environment interaction of common bean (Phaseolus vulgaris L.) lines in Ethiopia. Int J Plant Breed Crop Sci. 2016;3(2):135-44.

FAOSTAT. 2018. FAO statistical database. Rome: Food and Agriculture Organization of the United Nations. http://faostat.fao.org/. Accessed 20 Dec 2018.

Faris DG, Saxena KB, Mazumdar S, Singh U. Vegetable Pigeon pea: a promising crop in India. ICRISAT, Patancheru, A.P. 502324, India: International Crops Research Institute for the Semi-Arid Tropics; 1987.

Farshadfar E. Incorporation of AMMI stability value and grain yield in a single non-parametric index (GSI) in bread wheat. Pak J Biol Sci. 2008;1 1(14):1791-6.

Farshadfar E, Mahmodi N, Yaghotipoor A. AMMI stability value and simultaneous estimation of yield and yield stability in bread wheat (Triticum aestivum L.). Aust J Crop Sci. 2011;13:1837-44.

Gasura E, Setimela PS, Souta CM. Evaluation of the performance of sorghum genotypes using GGE biplot. Can J Plant Sci. 2015;95:1205-14.
Gauch HG, Zobel RW. Identifying mega-environment and targeting genotypes. Crop Sci. 1997:37:311-26.

Gebremedhin W, Firew M, Tesfye B. Stability analysis of food barley genotypes in Northern Ethiopia. Afr Crop Sci J. 2014;22:145-54.

GenStat. GenStat for Windows introduction. 15th ed. Hemel Hempstead: VSN International; 2015.

Gruneberg WJ, Manrique K, Zhang D, Hermann M. Genotype x environment interactions for a diverse set of sweet potato clones evaluated across varying ecographic conditions in Peru. Crop Sci. 2005;45:2160-71.

Hagos GH, Abay F. AMMI and GGE biplot analysis of bread wheat genotypes in the northern part of Ethiopia. J Plant Breed Genet. 2013;1 (1):12-8.

Hintsa GH, Abay F. Analysis AMMI AND GGE biplot analysis of bread wheat in the Northern part of Ethiopia. J Plant Breed Genet. 2013;01:12-8.

IBPGR and ICRISAT. Descriptors for pigeonpea [Cajanus Cajan (L.) Millsp]. Andhra Pradesh: International Crops Research Institute for the Semi-Arid Tropics; 1993.

Ikeogu UN, Nwofia GE. Yield parameters and stability of soybean as influenced by phosphorus fertilizer rates in two ultisols. Int J Adv Res Agric. 2013;1:20-8.

Islam MZ, Siddique MA, Rashid ESMH, Ahmed MS, Khalequzzaman M. Genetic Diversity in Sadajira rice (Oryza sativa L) germplasm. Agric. 2014;2(1):26-32.

Kamau SM. Utilization of multi-locational pigeon pea performance data for determination of stability parameters. A dissertation submitted in partial fulfillment of the requirements for the degree of Master of Science in Research Methods. Nairobi: Jomo Kenyatta University of Agriculture and Technology; 2013.

Kaya Y, Akcura M, Taner S. GGE biplot analysis of multi-environment yield trials in bread wheat. Turk J Agric. 2006;30:325-37.

Latha N, Audi P, Jones R. Supply of pigeonpea genetic resources in local markets of eastern Kenya. IFPRI Discussion Paper 00819, November 2008. Washington: International Food Policy Research Institute (IFPRI); 2008.

Lule D, Fetene M, De Villiers S, Tesfaye K. Additive main effects and multiplicative interactions (AMMI) and genotype by environment interaction (GGE) biplot analyses aid selection of high yielding and adapted finger millet varieties. J Appl Biosci. 2014;76(1):6291-303.

Mallikarjuna N, Saxena KB, Jadhav DR. Cajanus. In: Kole C, editor. Wild crop relatives: genomic and breeding resources. Berlin: Springer; 2011. p. 21-33. https://doi.org/10.1007/978-3-642-14387-8_2.

Mare M, Manjeru P, Ncube B, Sisito G. GGE biplot analysis of genotypes by environment interaction on Sorghum bicolor L. (Moench) in Zimbabwe. Afr J Plant Sci. 2017;11(7):308-19.

Mergeai G, Kimani P, Mwang'ombe A, Olubayo F, Smith C, Audi P, Baudoin JP, Roi R. A survey of pigeon pea production systems, utilization, and marketing in semi-arid lands of Kenya. Biotech Agron Soc Environ. 2001;5:145-53.

Michieka DO, der Pouw V. Soils and vegetation of Kiboko Range Research, Station Report 53. Nairobi: Kenya Soil Survey, Ministry of Agriculture; 1977.

Mitrovic B, Stanisavljevi D, Treski S, Stojakovic M, Ivanovic M, Bekavac G, Rajkovic M. Evaluation of experimental Maize hybrids tested in Multilocation trials using AMMI and GGE biplot analysis. Turk J Field Crops. 2012;17(1):35-40.

Moussa SAM, El-Aal HAA, El-Fadl NIA. Stability study of sweet potato yield and its component characters under different environments by joint regression analysis. J Hortic Sci Ornam Plants. 2011;3:43-54.

Mulema JMK, Olanya OM, Adipala E, Wagoire W. Stability of late blight resistance in population B potato clones. Potato Res. 2004;47:11-24

Mulema JKM, Adipala E, Olanya OM, Wagoire W. Yield stability analysis of late blight resistant potato selections. Exp Agric. 2008;44:145-55.

Mustapha M, Bakari HR. Statistical evaluation of genotype by environment interactions for grain yield in Millet (Pennisetum glaucum (L.) R. Br). Int J Eng Sci. 2014;3(9):07-16.

Ojwang JD, Nyankanga OR, Imungi J, Olanya OM. Plant characteristics and growth parameters of vegetable pigeon pea varieties in Kenya. HortTechnology. 2016a;26:97-105.

Ojwang JD, Nyankanga OR, Imungi J, Olanya OM. Growth parameters of vegetable pigeon pea varieties in Kenya. HortTechnology. 2016b;26:5-5.

Ojwang JD, Nyankanga OR, Olanya OM, Ukuku DO, Imungi J. Yield components of vegetable pigeon pea cultivars. Subtrop Agric Environ. 2016c;67:1-12. 
Ojwang D, Nyankanga R, Imungi J, Olanya M, Ukuku D. Cultivar preference and sensory evaluation of vegetable pigeon pea (Cajanus cajan) in eastern Kenya. Food Security. 2016d;8:757-67.

Osiru MO, Olanya OM, Adipala E, Lemaga B, Kapinga R. Stability of sweetpotato cultivars to Altenaria leaf and stem blight disease. J Phytopathol. 2009a; 157:172-80.

Osiru MO, Olanya OM, Adipala E, Kapinga R, Lemaga B. Yield stability analysis of Ipomoea batatas L. cultivars in diverse environments. Aust J Crop Sci. 2009b:3:213-20.

Pagi N, Darshan D, Ravindrababu Y, Pachchigar K, Soni N, Parmar L, Patel J, Chauhan R, Patel M. Phenotypic stability and GGE biplot analysis in pigeonpea [Cajanus cajan (L.) Millsp] genotypes across the environments. J Exp Biol Agric Sci. 2017;5:359.

Patil SP, Manjare MR, Kamdi SR, Dethe AM, Ingle MB. Stability analysis in sorghum (Sorghum bicolor L. Moench). Int J Plant Sci. 2007;2:70-5.

Phad DS, Madrap IA, Dalvi VA. Studies on genotype $\times$ environment interaction and stability in pigeon pea. Indian J Pulses Res. 2005;18:156-7.

Purchase JL. Parametric analysis to describe genotype $\times$ environment interaction and yield stability in winter wheat. Ph.D. Thesis. Bloemfontein: University of the Orange Free State; 1997.

Purchase $J$, Hatting $\mathrm{H}$. Genotype $\times$ environment interaction of winter wheat (Triticum aestivum L.) in South Africa: I. AMMI analysis of yield performance. S Afr J Plant Soil. 2000;17(3):95-100.

Rono JK, Cheruiyot EK, Othira JO, Njuguna VN, Macharia JK, Owuoche J, Oyier M, Kange A. Adaptability and stability study of selected sweet sorghum genotypes for ethanol production under different environments using AMMI analysis and GGE biplots. Sci World J. 2016;2016:14

Sameer KCV. Adaptability assessment for quantitative traits by stability analysis in pigeonpea, Cajanus cajan L. Millsp. Madras Agric J. 2018;97(10-12):344-6.

Sameer KCV. Adaptability assessment for quantitative traits by stability analysis in pigeonpea, Cajanus cajan L Millsp. Madras Agric J. 2010;97(10-12):344-6.

Samonte SOPB, Wilson LT, McClung AM, Medley JC. Targeting cultivars onto rice growing environments using AMMI and SREG GGE biplot analysis. Crop Sci. 2005;45:2414-24.

Saxena KB, Ravishankar K, Vijaya Kumar R, Sreejith KP, Srivastava RK. Vegetable pigeonpea-a high protein food for all ages. Information Bulletin No. 83. Patancheru 502 324. Andhra Pradesh: International Crops Research Institute for the Semi-Arid Tropics; 2010. p. 124.

Shiferaw B, Okello J, Muricho G, Omiti J, Silim SN, Jones R. Unlocking the potential of high value legumes in the semi-arid regions: Analyses of the pigeon pea value chains in Kenya. Nairobi: International Crops Research Institute for the Semi-Arid Tropics; 2008.

Shitaye H. AMMI, stability and GGE biplot analysis of durum wheat grain yield for genotypes tested under some optimum and high moisture areas of Ethiopia. Acad J Entomol 2015;8(3):132-9.
Silim SN, Gwataa ET, Coeb R, Omanga PA. Response of pigeonpea genotypes of different maturity duration to temperature and photoperiod in Kenya. Afr Crop Sci J. 2007;15(2):73-81.

Sreelakshmi CH, Shivani D, Sameer Kumar CV. Adaptability assessment for quantitative traits by stability analysis in pigeonpea, Cajanus cajan L. Millsp. Madras Agric J. 2010;97(10-12):344-6.

Tamene T, Tolesa G, Keneni T, Sefera M, Yeneneh B. G × E interaction and performance stability for grain yield in field pea (Pisum sativum L.) genotypes. Int J Plant Breed. 2013;7(2):116-23.

Tesfaye LM, D'Egidio D, Mohammed A. Analysis of multi-environment yield trials in durum wheat based on GGE-biplot. J Food Agric Environ. 2008;6(2):217-21.

Turner NC, Wright GC, Siddique KMH. Adaptation of grain legumes to waterlimited environments: selection for physiological, biochemical, and yield component characteristics for improved drought resistance. In: Saxena NP, editor. Management of agricultural drought: agronomic and genetic options. Enfield: Science Publishers Inc.; 2003. p. 43-80.

Upadhyaya HD, Reddy KN, Gowda CLL, Singh S. Identification and evaluation of vegetable type pigeonpea (Cajanus cajan (L.) Millsp.) in the world germplasm collection at ICRISAT gene bank. Plant Genet Resour Charact Util. 2010;8(2):162-70.

Yan W. GGE biplot a windows application for graphical analysis of multienvironment trial data and other types of two-way data. Agron J. 2001:93:1111-8.

Yan W, Hunt LA. Genetic and environmental causes of genotype by environment interaction for winter wheat yield in Ontario. Crop Sci. 2001;41:19-25.

Yan W, Kang MS. GGE biplot analysis: a graphical tool for breeders, geneticists and agronomists. 1st ed. Boca Raton: CRC Press LLC; 2003. p. 271.

Yan W, Rajcan I. Biplot analysis of test sites and trait relations of soyabean in Ontario. Crop Sci. 2002:42:11-20.

Yan W, Tinker NA. Biplot analysis of multi-environment trial data: principles and applications. Can J Plant Sci. 2006;86:623-45.

Yan W, Cornelius PL, Crossa J, Hunt LA. Two types of GGE biplots for analyzing multi-environment trial data. Crop Sci. 2001;41:656-63.

Yan W, Kang MS, Ma B, Woods S, Cornelius PL. GGE biplot vs. AMMI analysis of genotype-by-environment data. Crop Sci. 2007;47:643-55.

\section{Publisher's Note}

Springer Nature remains neutral with regard to jurisdictional claims in published maps and institutional affiliations.

\footnotetext{
Ready to submit your research? Choose BMC and benefit from:

- fast, convenient online submission

- thorough peer review by experienced researchers in your field

- rapid publication on acceptance

- support for research data, including large and complex data types

- gold Open Access which fosters wider collaboration and increased citations

- maximum visibility for your research: over $100 \mathrm{M}$ website views per year
}

At $\mathrm{BMC}$, research is always in progress.

Learn more biomedcentral.com/submissions 